\title{
Analysis of the innovative potential of micro and small businesses in Mexico and Colombia
}

\section{Análisis del potencial innovador de las micro y pequeñas empresas de México y Colombia}

SERRANO-TORRES, Ma. Guadalupe †**, QUEZADA-FLORES, Ma. De la Luz, ZAMBRANOVALDIVIESO, Óscar Javier and GONZALEZ-GALLARDO, Sofía del Carmen

Universidad Tecnológica de León

ID $1^{\text {st }}$ Author: Ma. Guadalupe, Serrano-Torres / ORC ID: 0000-0003-2229-6925

ID $1^{\text {st }}$ Coauthor: Ma. De la Luz, Quezada-Flores / ORC ID: 0000-0002-4726-2695

ID $2^{\text {nd }}$ Coauthor: Óscar Javier, Zambrano-Valdivieso / ORC ID: 0000-0003-0064-1062

ID $3^{\text {rd }}$ Coauthor: Sofía del Carmen, Gonzalez-Gallardo / ORC ID: 0000-0002-9217-3261

DOI: $10.35429 / J M M E .2019 .4 .3 .12 .19$

Received February 14, 2019; Accepted June 17, 2019

Abstract

The objective of this research is to present the results and comparative analysis between the countries Mexico and Colombia in the implementation of innovation, used as a tool for improvement in production, in the sales process, in the organization, in the promotion of products. And services, as a strategy of permanence in the market for micro and small companies in these countries. Surveys were randomly applied by students from both universities, the methodology applied for this research is quantitative in that it measures the percentage obtained as a result of the implementation of the innovative potential by entrepreneurs, 33,076 questionnaires were applied in the Mexican Republic and 4,050 surveys in Colombia. As a result, it was obtained that both countries agree that they offer products and services derived from the suggestions made by their clients. It is this questioning that has the highest percentage as a result of the use of innovation by companies in Mexico and Colombia. This research was carried out in 2018 and contributes with statistical data that allow us to increase and improve the level of innovation of the MIPES of Mexico and Colombia for the following years of life of the companies.

Innovative potential, Micro, Small businesses

\begin{abstract}
Resumen
El objetivo de esta investigación es presentar los resultados y análisis comparativo entre los países México y Colombia en la implementación de la innovación, utilizada como herramienta de mejora en la producción, en el proceso de ventas, en la organización, en la promoción de los productos y servicios, como estrategia de permanencia en el mercado para las micro y pequeñas empresas de dichos países. De forma aleatoria se aplicaron las encuestas por los alumnos de ambas universidades, la metodología aplicada para esta investigación es de carácter cuantitativa por que mide el porcentaje obtenido como resultado de la implementación del potencial innovador por parte de los empresarios, se aplicaron 33,076 cuestionarios en la República Mexicana y 4,050 encuestas en Colombia. Como resultados se obtuvo que ambos países coinciden en que ofrecen productos y servicios derivados de las sugerencias realizadas por sus clientes. Es este cuestionamiento el que tiene mayor porcentaje como resultado del uso de innovación por parte de las empresas de México y Colombia. Esta investigación fue realizada al año 2018 y contribuye con datos estadísticos que nos permiten incrementar y mejorar el nivel de innovación de las MIPES de México y Colombia para los siguientes años de vida de las empresas.
\end{abstract}

Potencial innovador y micro y pequeñas empresas

Citation: SERRANO-TORRES, Ma. Guadalupe, QUEZADA-FLORES, Ma. De la Luz, ZAMBRANO-VALDIVIESO, Óscar Javier and GONZALEZ-GALLARDO, Sofía del Carmen. Analysis of the innovative potential of micro and small businesses in Mexico and Colombia. RINOE Journal- Macroeconomics and monetary economy. 2019. 3-4: 12-19.

\footnotetext{
* Correspondence to Author (email: gserrano@utleon.edu.mx)

$\dagger$ Researcher contributing first author.
} 


\section{Introduction}

At present, micro and small enterprises are the backbone in the countries' economy because of the jobs they generate and the contribution to GDP. In Mexico and Colombia, they have a business representation above $90 \%$ for both countries, therefore the objective of the following research is to analyze the innovation potential of MIPES companies.

Colombia defines the SME according to its total assets and the number of employees (Law 905 of 2004), as can be seen in Table 1. In different reports it can be determined that the country's business structure establishes that between $92 \%$ and $97 \%$ corresponds to SMEs, while between $3 \%$ and $8 \%$ corresponds to large companies, hence the importance of developing research in this type of companies, given the impact they have on the economy of Colombia (Marulanda, López and López, 2016). Below is how companies are distributed in Mexico.

\begin{tabular}{|c|c|c|c|c|c|}
\hline Concept & Business & In \% & Busy staff & $\begin{array}{l}\text { Personne } \\
\text { l in } \%\end{array}$ & $\begin{array}{c}\text { Total } \\
\text { Gross } \\
\text { Productio } \\
\text { n PBT }\end{array}$ \\
\hline $\begin{array}{l}\text { Economic } \\
\text { units }\end{array}$ & $5,654,014$ & $100 \%$ & $29,642,421$ & $100 \%$ & $100 \%$ \\
\hline $\begin{array}{l}\text { Micro of 1-10 } \\
\text { workers }\end{array}$ & $5,331,735$ & 94.3 & $11,530,902$ & 38.9 & 9.8 \\
\hline $\begin{array}{l}\text { Small 11-50 } \\
\text { workers }\end{array}$ & 265,739 & 4.7 & $5,483,848$ & 18.5 & 9.5 \\
\hline \begin{tabular}{|l|} 
Medium 51- \\
250 employees
\end{tabular} & 45,232 & 0.8 & $4,920,642$ & 16.6 & 16.6 \\
\hline $\begin{array}{l}\text { Large more } \\
\text { than } 250 \\
\text { workers }\end{array}$ & 11,308 & 0.2 & $7,707,029$ & 26 & 64.1 \\
\hline
\end{tabular}

Table 1 Business representation of Mexico

Source of own elaboration with data from INEGI Economic Census 2014

MIPES in Mexico have a business representation of 5,597,474 units representing $99 \%$ of $100 \%$ of companies in Mexico, generating 17,014,750 jobs representing $57.40 \%$ of total jobs in the country.

\section{Justification}

Micro and small businesses have as their main mission to do the same thing differently or create a new need that distinguishes them from their main competitor. The MIPES have a business representation in Mexico of $99 \%$ and in Colombia with $96 \%$ data provided by INEGI (2017), these types of companies have the quality that of every three companies that are created only one will survive for more than three years.
This problem and challenge make innovation one of the main survival strategies for the MIPES both in the production processes and in its administration. Therefore, business innovation becomes a challenge and an obligation for these types of companies. However, because the innovation in the MIPES is analyzed in addition to the high rate of business representation and having the responsibility in generating jobs of more than $74 \%$ for both countries, it is very important to emphasize that they have a very important area of opportunity in National productivity and this is the contribution to the Gross Domestic Product, so in addition to achieving the permanence of companies through innovation, the site in productivity that we occupy worldwide Mexico and Colombia is increased.

\section{Problem}

Currently, the MIPES have as an area of opportunity and is to remain for more than three years and exceed the survival statistics for the companies in question. As well as increase productivity rates. Innovation represents talking about technology is the first thing that comes to mind of who runs the company and it is in the belief that this represents a cost, currently there is a current phenomenon that comes to provide a very important tool to the innovation and is the 4.0 technology that tells us about using technology but not only that but innovating in the processes and administrative procedures that make the company more productive in its entirety.

\section{Research questions}

- Do I promote that employees propose changes in my products, services and processes?

- Do I frequently offer new products or services based on the suggestion of my clients?

- Do I focus a lot on offering innovative products or services that distinguish the company?

- Development or payment to innovate my production or distribution processes?

- Development or payment to innovate the products or services I offer?

SERRANO-TORRES, Ma. Guadalupe, QUEZADA-FLORES, Ma. De la Luz, ZAMBRANO-VALDIVIESO, Óscar Javier and GONZALEZGALLARDO, Sofía del Carmen. Analysis of the innovative potential of micro and small businesses in Mexico and Colombia. RINOE JournalMacroeconomics and monetary economy. 2019 
- Development or payment to innovate the way in which I sell my product or service (Design, packaging, promotion, how to quote, etc.)?

- Development or payment to innovate the way I organize the company?

- Do I attend fairs, courses, congresses or other activities related to the business?

\section{Hypothesis}

Micro and small business executives are not interested in increasing innovation levels as a factor of permanence and strategy to raise productivity indicators nationally and globally.

\section{Overall objective}

Analyze the innovative potential of micro and small businesses in Mexico and Colombia, to promote the continuity of MIPES and in turn use innovation as an instrument to raise productivity levels at national and global levels.

\section{Theoretical framework}

Rubio and Aragón (2002), carried out a study of innovation as a success factor of the MIPES, commenting that the greater the areas with innovation, the greater the success and permanence. On the other hand Estrada, García and Sánchez (2009), agree that innovation in products and processes, having a high technological level in machinery and equipment supported by a strategic plan. By increasing productivity levels with technological use in processes, the financial results of the company can be improved.

According to the Global Innovation Index 2018, Mexico is at site 56 of an analysis of 126 countries, where Switzerland is ranked number one, site 126 is for the Country of Yemen. Each year, the Global Innovation Index classifies the innovation performance of almost 130 economies around the world. Next, we present the leading countries and major regions in innovation by score. In North America, the United States and Canada are leaders in innovation; in Europe first is Switzerland, followed by the Netherlands and Sweden; in North Africa and West Asia, Israel, Cyprus and the United Arab Emirates occupy the first places in innovation; In Southeast Asia, East Asia and Oceania, the leading innovation countries are:
Singapore, Republic of Korea and Japan; In Latin America and the Caribbean, the leaders in innovation are the countries of Chile, Costa Rica and Mexico; In Sub-Saharan Africa, the leading countries are South Africa, Mauritania and Kenya; In Central Asia and South Asia, the first places in innovation are: India, Iran and Kazakhstan. Global Innovation Index (Soumitra Dutta, 2018).

It is very important to note that innovation is the entrepreneurial capacity of the entrepreneur, where others see difficulties, he sees opportunities for development. The innovator turns the company's problems into sources of innovation. (Drucker, 1986).

Definition of innovation for the OECD tells us that "Innovation consists in the introduction of new goods, services and processes, or the introduction of a marketing or organizational method applied to business practices to work organization or external relations" (Zozoya, 2005).

For this research innovation is to do the same as my main competitors but in a different way in the shortest time and at the best cost.

\section{Methodology to be developed}

Give the meaning of the variables in linear writing and it is important to compare the criteria used

\section{Results}

This research is developed in the analysis of eight questions, which are analyzed below.;

1) Do I promote that employees propose changes in my products, services and processes?

\begin{tabular}{|l|r|r|r|r|}
\hline SCALE & \multicolumn{2}{c}{ MEXICO } & \multicolumn{3}{c|}{ COLOMBIA } \\
& \multicolumn{1}{c}{ Business } & \multicolumn{3}{c|}{ Business } \\
\hline Strongly agree & 6,644 & $20 \%$ & 854 & $21 \%$ \\
\hline In agreement & 12,241 & $37 \%$ & 1,779 & $44 \%$ \\
\hline In disagreement & 6,758 & $20 \%$ & 779 & $19 \%$ \\
\hline Strongly disagree & 2,236 & $7 \%$ & 212 & $5 \%$ \\
\hline I dont know & 4,882 & $15 \%$ & 398 & $10 \%$ \\
\hline I do not answer & 315 & $1 \%$ & 28 & $1 \%$ \\
\hline Total surveys & $\mathbf{3 3 , 0 7 6}$ & $\mathbf{1 0 0 \%}$ & $\mathbf{4 , 0 5 0}$ & $\mathbf{1 0 0 \%}$ \\
\hline
\end{tabular}

Table 2 Iencourage employees to propose changes in my products, services and processes

Source: own elaboration 
In Mexico, $57 \%$ and in Colombia $65 \%$ of the companies surveyed agree to promote that employees propose changes in their company's products, services and processes.

I promote that employees propose changes in my products, services and processes

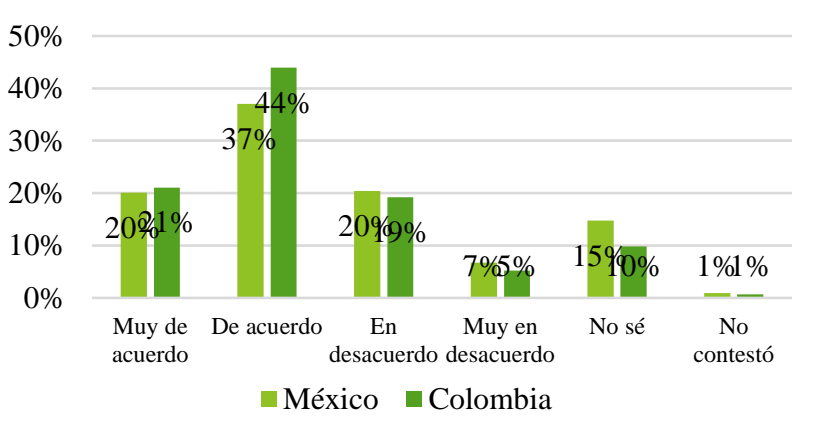

Graphic 1 I promote that employees propose changes in my products, services and processes. Source: own elaboration

Graphic 1 shows the results in a comparative way, from Mexico and Colombia where a variation of $8 \%$ higher for Colombia is shown regarding this question.

We continue with question number 2 :

2) Do I frequently offer new products or services based on the suggestion of my clients?

\begin{tabular}{|l|r|r|r|r|}
\hline SCALE & \multicolumn{2}{c}{ MEXICO } & \multicolumn{3}{c|}{ COLOMBIA } \\
& Business & \multicolumn{1}{c|}{ \% } & \multicolumn{1}{c|}{ Business } \\
\hline Strongly agree & 8,725 & $26 \%$ & 1,145 & $28 \%$ \\
\hline In agreement & 15,182 & $46 \%$ & 2,098 & $52 \%$ \\
\hline In disagreement & 4,919 & $15 \%$ & 483 & $12 \%$ \\
\hline Strongly disagree & 1,451 & $4 \%$ & 133 & $3 \%$ \\
\hline I dont know & 2,605 & $8 \%$ & 174 & $4 \%$ \\
\hline I do not answer & 194 & $1 \%$ & 17 & $0 \%$ \\
\hline Total surveys & $\mathbf{3 3 , 0 7 6}$ & $\mathbf{1 0 0 \%}$ & $\mathbf{4 , 0 5 0}$ & $\mathbf{1 0 0 \%}$ \\
\hline
\end{tabular}

Table 3 I frequently offer new products or services based on the suggestion of my clients

Source: own elaboration

It is worth mentioning that in the question in table number 2 it is the one that obtained the highest score of the 10 questions of this investigation; representing for Mexico $72 \%$ and for Colombia $80 \%$ of businessmen who answered agree to offer suitable products based on the suggestion of their customers, this results in the businessmen in analysis consider what their client needs and create or They adapt their products to the needs of their customers.
The comparative analysis between the countries in question is presented below.

\section{I frequently offer new products or services based on suggestions from my clients}

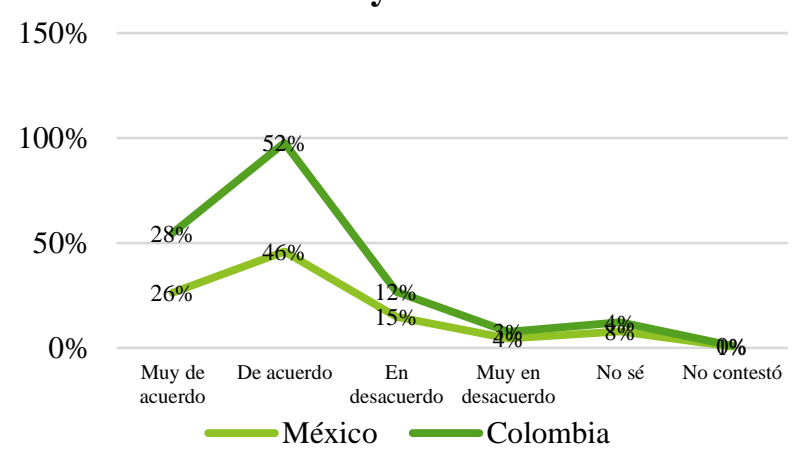

Graphic 2 I frequently offer new products or services based on the suggestion of my clients

Source of own elaboration

In the graphic number 2 we observe $72 \%$ for Mexico and $80 \%$ acceptance of question number two, which gives us as variation $8 \%$ for Colombia and turns out to be the most accepted point for the directors of the MIPES regarding the Innovation theme Below is question number three:

3) I focus a lot on offering innovative products or services that distinguish the company?

\begin{tabular}{|l|r|r|r|r|}
\hline SCALE & \multicolumn{2}{c}{ MEXICO } & \multicolumn{3}{c|}{ COLOMBIA } \\
& Business & \multicolumn{2}{c|}{ \% } & \multicolumn{2}{c|}{ Business } \\
\hline Strongly agree & 8,935 & $27 \%$ & 1,137 & $28 \%$ \\
\hline In agreement & 13,500 & $41 \%$ & 1,931 & $48 \%$ \\
\hline In disagreement & 5,571 & $17 \%$ & 606 & $15 \%$ \\
\hline Strongly disagree & 1,574 & $5 \%$ & 129 & $3 \%$ \\
\hline I dont know & 3,245 & $10 \%$ & 223 & $6 \%$ \\
\hline I do not answer & 251 & $1 \%$ & 24 & $1 \%$ \\
\hline Total surveys & $\mathbf{3 3 , 0 7 6}$ & $\mathbf{1 0 0 \%}$ & $\mathbf{4 , 0 5 0}$ & $\mathbf{1 0 0 \%}$ \\
\hline
\end{tabular}

Table 4 I focus a lot on offering innovative products or services that distinguish the company

Source: own elaboration

The table above shows the results of question three for Mexico, resulting in $68 \%$ and $76 \%$ of MIPES entrepreneurs who agree to offer innovative products and services that distinguish the company, this results in that company executives care about offering unique and innovative products that distinguish them from competitors. Now in graph number three the comparative analysis is made in this question for Mexico and Colombia. 


\section{I focus a lot on offering innovative products or services that distinguish the company.}



Graphic 3 I focus a lot on offering innovative products or services that distinguish the company

Source: own elaboration

In the previous graph we can see that Mexico has a $68 \%$ and Colombia a $76 \%$ therefore this last country has a variation of 8 points compared to Mexico regarding this questioning. Next, question number four is presented:

4) Development or payment to innovate my production or distribution processes?

\begin{tabular}{|c|c|c|c|c|}
\hline \multirow[t]{2}{*}{ SCALE } & \multicolumn{2}{|l|}{ MEXICO } & \multicolumn{2}{|c|}{ COLOMBIA } \\
\hline & Business & $\%$ & & Business \\
\hline Strongly & 4,956 & $15 \%$ & 623 & $15 \%$ \\
\hline In agreemen & 10,083 & $30 \%$ & 1,390 & $34 \%$ \\
\hline In disagre & 8,297 & $25 \%$ & 1,111 & $27 \%$ \\
\hline Strongly & 2,798 & $8 \%$ & 310 & $8 \%$ \\
\hline I don & 6,298 & $19 \%$ & 544 & $13 \%$ \\
\hline I do not answer & 644 & $2 \%$ & 72 & $2 \%$ \\
\hline Total surveys & $\mathbf{3 3 , 0 7 6}$ & $100 \%$ & 4,050 & $100 \%$ \\
\hline
\end{tabular}

Table 5 Development or payment to innovate my production or distribution processes?

Source: own elaboration

With regard to the results generated in question number four, it results in $45 \%$ for Mexico and $49 \%$ for Colombia. These results show us the interest in betting or the investment by the entrepreneur to innovate in their production processes. It is important to highlight at this point the place that Mexico occupies worldwide in the innovation index.

\section{Development or payment to innovate my production and distribution} processes

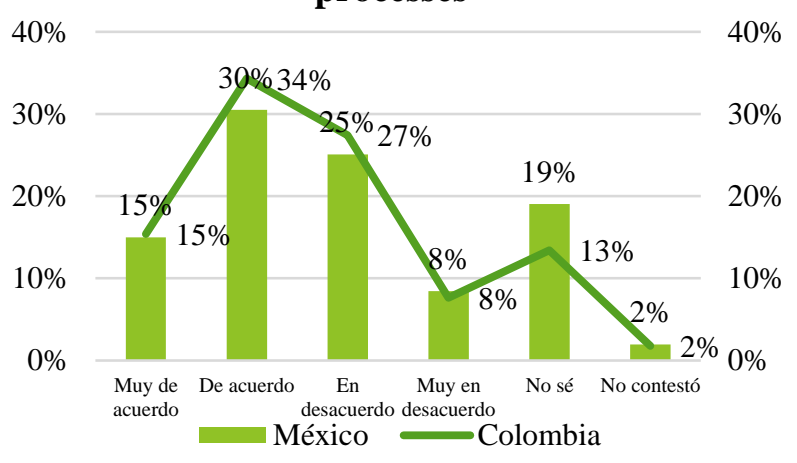

Graphic 4 Development or payment to innovate my production and distribution processes Source: own elaboration

Graphic four shows the comparative analysis of this question and the variation for each country of analysis is 5\%, with more investment from Colombia by its managers of micro and small companies. Next, question number five of this investigation is made.

5) Development or payment to innovate the products or services I offer?

\begin{tabular}{|l|r|r|r|r|}
\hline SCALE & \multicolumn{2}{c}{ MEXICO } & \multicolumn{2}{c|}{ COLOMBIA } \\
& Business & \multicolumn{1}{c|}{ \% } & \multicolumn{1}{c|}{ Business } \\
\hline Strongly agree & 5,206 & $16 \%$ & 623 & $15 \%$ \\
\hline In agreement & 10,431 & $32 \%$ & 1,390 & $34 \%$ \\
\hline In disagreement & 7,947 & $24 \%$ & 1,111 & $27 \%$ \\
\hline Strongly disagree & 2,856 & $9 \%$ & 310 & $8 \%$ \\
\hline I dont know & 5,988 & $18 \%$ & 544 & $13 \%$ \\
\hline I do not answer & 648 & $2 \%$ & 72 & $2 \%$ \\
\hline Total surveys & $\mathbf{3 3 , 0 7 6}$ & $\mathbf{1 0 0 \%}$ & $\mathbf{4 , 0 5 0}$ & $\mathbf{1 0 0 \%}$ \\
\hline
\end{tabular}

Table 6 Development or payment to innovate the products or services I offer

Source: own elaboration

In the previous table, $48 \%$ were obtained for Mexico and 49\% for Colombia. This point we see an area of opportunity to increase investment and implement innovation in products that are developed by the MIPES in Mexico-Colombia. 


\section{Development or payment to innovate} the products or services I offer

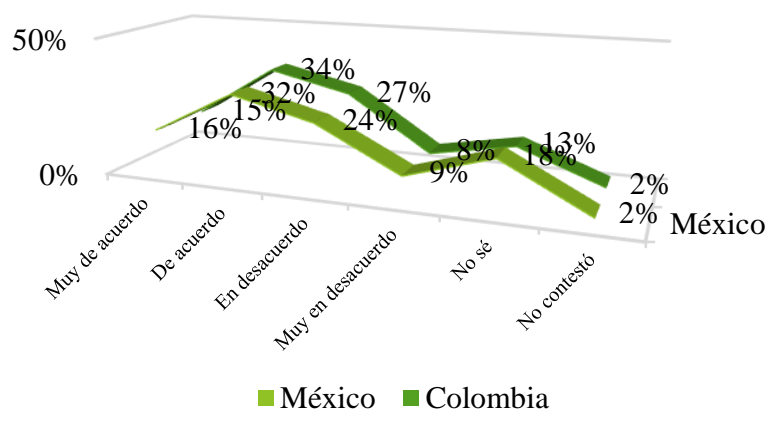

Graphic 5 Development or payment to innovate the products or services I offer Source: own elaboration

In the previous graph it can be seen that with respect to this question there is a variation of $1 \%$ of Mexico-Colombia and that there is notably an area of opportunity in the investment by the managers of MSEs. Next you have question number six.

6) Development or payment to innovate the way I sell my product or service. (Design, packaging, promotion, form of quotation, etc.)

\begin{tabular}{|l|r|r|r|r|}
\hline & \multicolumn{2}{c}{ MEXICO } & \multicolumn{2}{c|}{ COLOMBIA } \\
SCALE & Business & \% & \multicolumn{1}{c|}{ Business } \\
\hline Strongly agree & 5,358 & $16 \%$ & 684 & $17 \%$ \\
\hline In agreement & 9,894 & $30 \%$ & 1,386 & $34 \%$ \\
\hline In disagreement & 7,887 & $24 \%$ & 1,068 & $26 \%$ \\
\hline Strongly disagree & 2,877 & $9 \%$ & 310 & $8 \%$ \\
\hline I dont know & 6,382 & $19 \%$ & 517 & $13 \%$ \\
\hline I do not answer & 678 & $2 \%$ & 85 & $2 \%$ \\
\hline Total surveys & $\mathbf{3 3 , 0 7 6}$ & $\mathbf{1 0 0 \%}$ & $\mathbf{4 , 0 5 0}$ & $\mathbf{1 0 0 \%}$ \\
\hline
\end{tabular}

Table 7 Development or payment to innovate the way I sell my product or service. (Design, packaging, promotion, form of quotation, etc.)

Source: own elaboration

In the previous table, the managers of the companies under study $46 \%$ said they agreed in Mexico to pay to innovate and $51 \%$ for Colombia to innovate in the way of offering and selling their product.

\section{Development or payment to innovate the way I sell my product or service. (Design, packaging, promotion, form of quotation, etc.}

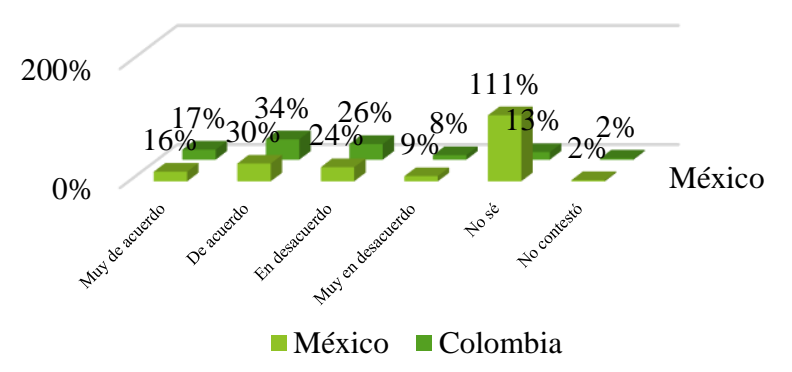

Graphic 6 Development or payment to innovate the way I sell my product or service

Source: own elaboration

The above chart shows a variation in how MIPES agree on how to innovate to sell their products there is a $6 \%$ variation with respect to Mexico and Colombia. presented:

Now question number seven is

7) Development or payment to innovate the way in which I organize the company.

\begin{tabular}{|c|c|c|c|c|}
\hline SCALE & \multicolumn{2}{|l|}{ MEXICO } & \multicolumn{2}{|c|}{ COLOMBIA } \\
\hline Strongly agre & 4,547 & $14 \%$ & 618 & $15 \%$ \\
\hline In agreement & 9,820 & $30 \%$ & 461 & $36 \%$ \\
\hline In disagreement & 8,484 & $26 \%$ & 1,077 & $27 \%$ \\
\hline Strongly disagree & 3,208 & $10 \%$ & 332 & $8 \%$ \\
\hline I dont know & 6,318 & $19 \%$ & 490 & $12 \%$ \\
\hline $\mathrm{I} \mathrm{do}$ & 699 & $2 \%$ & 72 & $2 \%$ \\
\hline Total survey: & 3,076 & $100 \%$ & 4,050 & $100 \%$ \\
\hline
\end{tabular}

Table 8 Development or payment to innovate the way in which I organize the company

Source: self made

The previous table shows a result of $44 \%$ for Mexico and $51 \%$ for Colombia. As soon as I agree to pay to innovate in the way of organizing the company.

Below is graph number seven that shows the percentage of variation between Mexico and Colombia. 


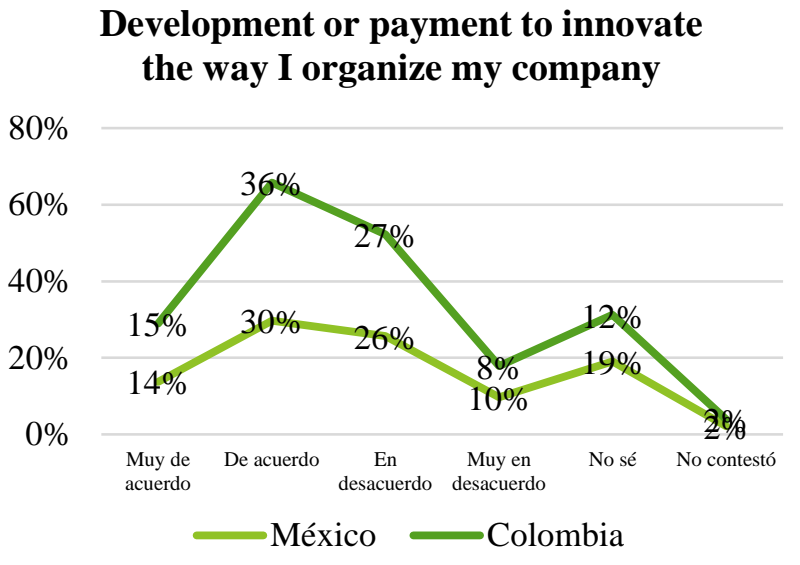

Graphic 7 Development or payment to innovate the way I organize my company

Source: own elaboration

The previous graph shows a $7 \%$ variation of Mexico against Colombia in terms of investment in innovation to improve the way of organizing the company.

Below is question number eight and last of this investigation.

8) 9) Do I attend fairs, courses, congresses or other activities related to the business?

\begin{tabular}{|l|r|r|r|r|}
\hline & \multicolumn{2}{c}{ MEXICO } & \multicolumn{2}{c|}{ COLOMBIA } \\
SCALE & \multicolumn{1}{c|}{ Business } & \multicolumn{1}{c|}{$\%$} & Business \\
\hline Strongly agree & 5,713 & $17 \%$ & 885 & $22 \%$ \\
\hline In agreement & 8,346 & $25 \%$ & 1,304 & $32 \%$ \\
\hline In disagreement & 7,492 & $23 \%$ & 916 & $23 \%$ \\
\hline Strongly disagree & 3,710 & $11 \%$ & 351 & $9 \%$ \\
\hline I dont know & 6,960 & $21 \%$ & 510 & $13 \%$ \\
\hline I do not answer & 855 & $3 \%$ & 84 & $2 \%$ \\
\hline Total surveys & $\mathbf{3 3 , 0 7 6}$ & $\mathbf{1 0 0 \%}$ & $\mathbf{4 , 0 5 0}$ & $\mathbf{1 0 0 \%}$ \\
\hline
\end{tabular}

Table 9 Do I attend fairs, courses, congresses or other activities related to the business?

Source: own elaboration

The above table shows the results in the question agree on the attendance of fairs, courses and congresses to improve business innovation with $42 \%$ for Mexico and 54\% for Colombia.

Now we present the graph with the variations of Mexico and Colombia regarding the attendance of fairs, courses and congresses.

\section{I attend fairs, courses, congresses, or other activities related to the business}



Graphic 8 Do I attend fairs, courses, congresses or other activities related to the business?

Source: own elaboration

The above graph shows a variation of $12 \%$ with respect to Mexico and Colombia, having the highest percentage for Colombia, showing its greatest interest in this question and positively increasing innovation for the MIPES under study.

\section{Acknowledgments}

In particular, the three members of the academic body would like to thank the Universidad Tecnológica de León UTL, for sponsoring the publication of this research article on innovation in micro and small businesses.

\section{Conclusions}

Next, the results obtained in the analyzed MIPES of Mexico and Colombia are analyzed. The question with greater acceptance and agreement was the number two entrepreneurs agree in $72 \%$ and $80 \%$ in offering products that their customers suggest and because of their need and adequacy. Now it is very important to mention the question that has the greatest area of opportunity and that obtained the lowest research score and this is question number seven this is the innovation in the organization of the company with $43 \%$ for Mexico and $51 \%$ for Colombia Concluding that the latter country has greater acceptance in terms of innovation in the way of organizing and running the company. 


\begin{tabular}{|c|c|c|c|}
\hline Question & Mexico & Colombia & Variation \\
\hline $\begin{array}{l}\text { 1) I promote that } \\
\text { employees propose } \\
\text { changes in my products, } \\
\text { services and processes. }\end{array}$ & $57 \%$ & $65 \%$ & $8 \%$ \\
\hline $\begin{array}{lr}\text { 2) I frequently offer } \\
\text { new products } & \text { or } \\
\text { services based } & \text { on } \\
\text { suggestions from } & \text { my } \\
\text { clients. } & \\
\end{array}$ & $72 \%$ & $80 \%$ & $8 \%$ \\
\hline $\begin{array}{l}\text { 3) I focus a lot on } \\
\text { offering innovative } \\
\text { products or services } \\
\text { that distinguish the } \\
\text { company. }\end{array}$ & $68 \%$ & $76 \%$ & $8 \%$ \\
\hline $\begin{array}{l}\text { 4) Development or } \\
\text { payment to innovate my } \\
\text { production or } \\
\text { distribution processes. }\end{array}$ & $45 \%$ & $50 \%$ & $4 \%$ \\
\hline $\begin{array}{l}\text { 5) Development or } \\
\text { payment to innovate the } \\
\text { products or services I } \\
\text { offer. }\end{array}$ & $47 \%$ & $50 \%$ & $2 \%$ \\
\hline $\begin{array}{l}\text { 6) Development or } \\
\text { payment to innovate the } \\
\text { way I sell my product or } \\
\text { service. (Design, } \\
\text { packaging, promotion, } \\
\text { form of quotation, etc.) }\end{array}$ & $46 \%$ & $51 \%$ & $5 \%$ \\
\hline $\begin{array}{l}\text { 7) Development or } \\
\text { payment to innovate } \\
\text { the way in which I } \\
\text { organize the company. }\end{array}$ & $43 \%$ & $51 \%$ & $8 \%$ \\
\hline $\begin{array}{l}\text { 8) I attend fairs, } \\
\text { courses, congresses, or } \\
\text { other activities related } \\
\text { to the business. }\end{array}$ & $43 \%$ & $54 \%$ & $12 \%$ \\
\hline
\end{tabular}

Table 10 Comparison of innovation of the MIPES of Mexico and Colombia

Source: own elaboration

The previous table summarizes the results and variations in each of the eight questions that were analyzed in the innovation of the micro and small comparative company between Mexico and Colombia. In the indices that are made in terms of innovation worldwide, Mexico and Colombia are countries that require an increase to reach the first places, currently being at sites 53 and 60 of 117, with almost half of the sites being scaled world index analysis.

\section{References}

Drucker, P. (1986). La innovación y el empresario innovador, principios y prácticas. Buenos Aires: Suramericana.

Estrada, R., García Pérez de Lema y Sánchez, V. (2009). Factores determinantes del éxito competitivo en las Pyme: Estudio empírico en México.
Instituto Nacional de Estadística y Geografía INEGI. (2014). Resultados definitivos Censos Económicos (2014), recuperado de: https://www.inegi.org.mx/contenidos/programa s/ce/2014/doc/pprd_ce2014.pdf

Molina, S. R. (2016). Mipymes una mirada de los expertos e investigadores. México, D.F.Pearson.

Rubio, A. y Aragón, A. (2002), Factores explicativos del Éxito competitivo. Un estudio empírico en la PYME. Cuadernos de gestión.

Soumitra Dutta, B. L.-V. (Agosto de 2018). Indice Global de Innovación. Recuperado el 05 de 08 de 2018, de http://www.wipo.int/edocs/pubdocs/en/wipo_pu b_gii_2018.pdf.

Organización para la Cooperación y Desarrollo Económico (OCDE). (2010). OCDE. Obtenido de http://www.oecd.org/sti/45302715.pdf

Organización para la Cooperación y el Desarrollo Económicos (OCDE). (2005). Manual de Oslo. Madrid: Tragsa.

Surdez-Pérez E. G., Sandoval-Caraveo M.C., Aguilar-Morales N., El empresario administrador de empresas pequeñas industriales consolidadas en Villahermosa, Tabasco. Hitos de Ciencias Económico Administrativas 2007; 13 (35): 17-28. Recuperado en: https://www.ecorfan.org/series/cap20.pdf

Zozoya, N. (2005). Ipyme.org. Obtenido de http://www.ipyme.org/Publicaciones/innovacio n2005.pdf
SERRANO-TORRES, Ma. Guadalupe, QUEZADA-FLORES, Ma. De la Luz, ZAMBRANO-VALDIVIESO, Óscar Javier and GONZALEZGALLARDO, Sofía del Carmen. Analysis of the innovative potential of micro and small businesses in Mexico and Colombia. RINOE JournalMacroeconomics and monetary economy. 2019 